\title{
Uniwersalne układy wejść - wyjść do zastosowania w pojazdach szynowych z wykorzystaniem mikrosystemu cyfrowego PSoC CY29466 firmy CYPRESS
}

\begin{abstract}
W artykule opisano uniwersalne uktady wejść - wyjść zrealizowane dla mikrosystemu cyfrowego (mikrokontrolera) PSoC CY29466 firmy CYPRESS. Układ ten umożliwia zamiane sygnałów analogowych z reluktancyjnych czujników na dane wejściowe do mikroprocesora. Przekształca sygnaty analogowe na równoważne sygnaty cyfrowe, umożliwia zbieranie sygnatów analogowych $i$ cyfrowych, wejściowych $i$ wyjściowych $w$ celu ich dalszej obróbki do wspótpracy ze sterownikami przemystowymi, komputerami i innymi układami sterujacymi. Mikrokontroler może także realizować akwizycje danych z różnych układów wejściowych. Praca jest kontynuacja artykułu „Przyszłościowe wspótbieżne mikroprocesorowe inteligentne systemy mechatroniczne w sterowaniu i diagnostyce pojazdów szynowych" przedstawione w czasopiśmie „Pojazdy Szynowe” 4/2007; 1/2008; 2/2008.

Artykut powstat w wyniku realizacji projektu badawczego KBN 4 T $12 C 04929$

pt." Rozproszone wspótbieżne mikroprocesorowe inteligentne podsystemy mechatroniczne w sterowaniu i diagnostyce pojazdów szynowych".
\end{abstract}

\section{1 . Nowe układy wejściowo - wyjściowe dla pojaz- dów szynowych}

Dynamiczny rozwój technologii elementów elektronicznych, nowe generacje mikrokontrolerów, procesorów i metody komunikacji cyfrowej umożliwiają bardzo szybki zmiany i nowe kierunki rozwoju przemysłowych systemów automatyki. Szczególnie widoczne są zmiany w projektowaniu funkcji danego systemu i jej realizacji sprzętowej i programowej. Klasyczne analogowe układy automatyki są zastępowane systemami komputerowymi czasu rzeczywistego. Współczesne układy przemysłowe podlegają bardzo dynamicznym zmianom wynikającym $\mathrm{z}$ rozwoju samych technologii, ich uwarunkowań ekonomicznych i szybkich zmian $w$ informatyce i elektronice. Obecnie obserwuje się gwałtowny wzrost wymagań stawianych układom automatyki. Wymagania te można ujać $\mathrm{w}$ następujących punktach [3]:

- pożądane są narzędzia integrujące proces projektowania układu automatyki, sprzętu komputerowego i oprogramowania

- powstanie zapotrzebowania na nowe unikatowe systemy pomiarowe parametrów układu automatyki

- zwiększenie dokładności i prędkości systemów pomiarowych

- zapotrzebowanie na systemy pomiarowe o dużej dynamice zakresu pomiarowego

- konieczność wprowadzenia równoległych procesów kontrolno pomiarowych

- potrzeba zastosowania systemów rozproszonych

- bardzo dobre parametry komunikacyjne dla wymiany danych procesowych.
Rozwój układów automatyki wymaga stosowania nowych rozwiązań mikroprocesorów, układów wejść i wyjść oraz układów komunikacyjnych. Wymagania takie spełniają mikrosystemy cyfrowe integrujące $\mathrm{w}$ jednej strukturze m.in. blok sprzętowy i rdzeń mikroprocesorowy (systemy o realizacji sprzętowo - programowej). Jest to rodzina układów, o której pierwsze wzmianki w publikacjach naukowych pojawiły się w połowie lat 90-tych. Układy takie buduje wiele firm, takie jak: ATMEL, CYPRESS i TRISCEND. Wspólną cechą tych układów jest posiadanie rdzenia mikroprocesorowego oraz programowalnej części sprzętowej. Pod pojęciem mikrosystem cyfrowy rozumie się taki układ scalony, który w swej strukturze integruje (obok innych) właśnie te dwa elementy. Umożliwia to zmniejszenie rozmiarów gabarytowych produktu, zużycia energii, a nawet kosztów związanych z produkcją w porównaniu do rozwiązań bazujących na łączeniu osobno struktur sprzętowych i mikroprocesorowych. W projekcie badawczym do realizacji układu wejść - wyjść zastosowano mikrosystem cyfrowy PSoC CY29466 firmy CYPRESS.

\section{Klasyczna budowa systemu komputerowego stosowana w pojazdach szynowych}

Tradycyjne układy komputerowych systemów sterowania są najczęściej kontynuacją rozwiązań analogowych. Na rys. 1 przedstawiono w sposób uproszczony budowę takiego układu. Analogowe sygnały wejściowe po uformowaniu w bloku elektroniki analogowej, zostają w przetwornikach analogowo - cyfrowych zamienione na wielkości numeryczne. Mikroprocesor po wykonaniu odpowiednich obliczeń 


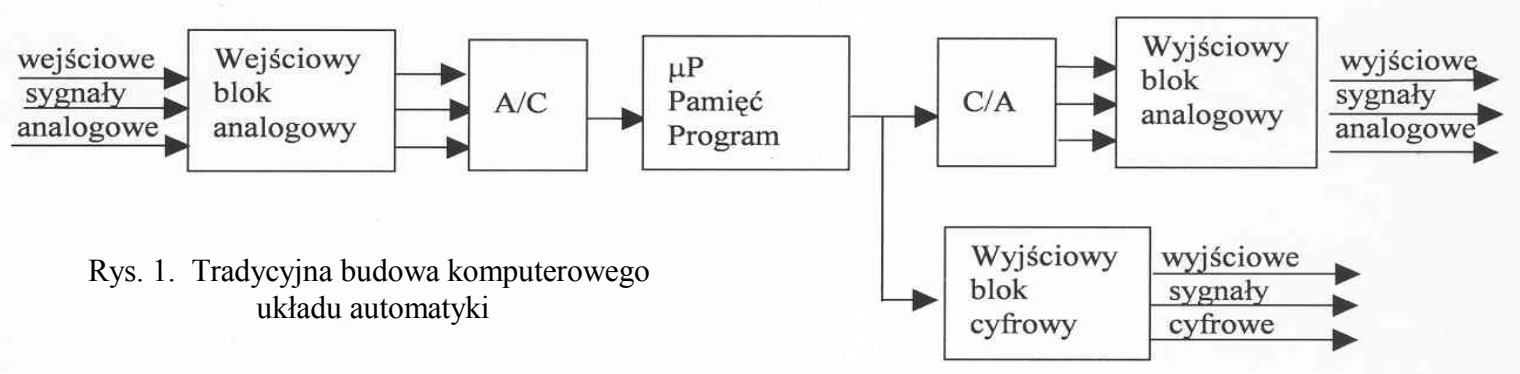

przekazuje wyniki do przetworników cyfrowo - analogowych, których sygnały analogowe po odpowiednim uformowaniu przesyłane są do układu automatyki. Cyfrowe sygnały wyjściowe po odpowiednim uformowaniu $\mathrm{w}$ bloku elektroniki cyfrowej zostaja przekazane do urządzeń automatyki.

\section{Struktura sprzętu i oprogramowania kompute- rowego systemu czasu rzeczywistego}

Przedstawiona na rys. 1 klasyczna struktura komputerowego systemu czasu rzeczywistego ulega obecnie dużym zmianom. Jako jedną z pierwszych zmian należy zauważyć zanik

klasycznego bloku analogowego i przesunięcie strefy cyfrowej w kierunku sensorów

pomiarowych. Podejście takie polepsza własności pomiarowe, takie jak dokładność i dynamika zakresu pomiarowego. Zastosowanie najnowszych układów elektronicznych jako elementów sprzęgających, takich jak np. UIT (Uniwersalny interfejs do przetworników [3]) eliminuje nie tylko tradycyjne układy analogowe, lecz również przetworniki analogowo - cyfrowe $\mathrm{A} / \mathrm{C}$. Rośnie rola układów licznikowych, do których podłączone są bezpośrednio sensory pomiarowe. Jednoukładowe komputery jako mikrokontrolery posiadaja już po kilka układów rozbudowanych liczników. Maleje również rola przetworników $\mathrm{C} / \mathrm{A}$ i analogowych bloków dla sygnałów wyjściowych. Wprowadzenie cyfrowo sterowanych układów wykonawczych w układach automatyki poprawia dokładność, dynamikę sterowania procesem, zmniejsza wrażliwość na zakłócenia i zwiększa niezawodność pracy.

Największe zmiany nastapiły jednak w koncepcji rozwiązania idei współpracy sytemu komputerowego $\mathrm{z}$ otoczeniem. Na rys. 2 przedstawiono dwa podstawowe rozwiązania: transformujący i reaktywny. System transformujący (rys. 2a), to system który charakteryzuje się tym, że każdy $\mathrm{z}$ jego elementów składowych (a w szczególnych przypadkach nawet cały system) czeka na pojawienie się gotowych danych na jego wejściu, co jest odpowiednio sygnalizowane, po czym następuje przetwarzanie danych i dane te są przekazywane na wyjście, co również jest sygnalizowane. Po takim przetworzeniu system transformujący (lub jego składowe) przechodzą w stan oczekiwania (czas $\Delta \mathrm{t}$ ) na pojawienie się kolejnego kompletu danych na wejściu.
System reaktywny (rys. 2b) nie funkcjonuje w tak przewidywanym scenariuszu czasowym jak systemy transformujący. Ich główną cechą charakterystyczną jest to, że dane wejściowe takiego systemu mogą się pojawiać zupełnie dowolnie, tzn. nie przyjmuje się żadnych założeń, co do tego, na których wejściach i kiedy pojawiają się dane, a w przypadku systemów czasu rzeczywistego oczekuje się, że odpowiedź układu będzie natychmiast, tzn. czas odpowiedzi jest niezauważalny dla otoczenia (ang. perfect synchrony hypothesis).

a.)

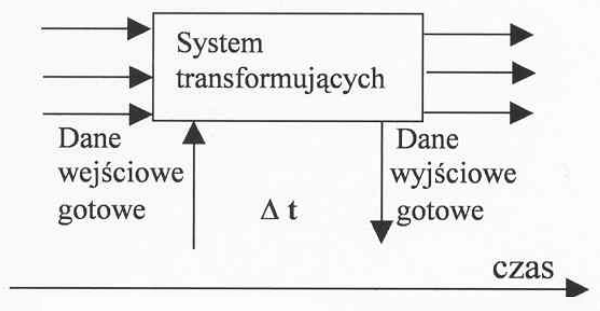

b.)

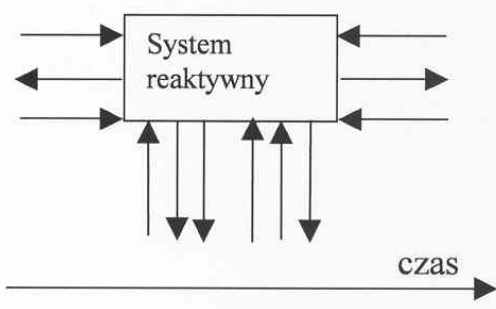

Rys. 2. System transformujący i reaktywny

Systemy reaktywne charakteryzują się tym, że:

- są sterowane zdarzeniami

- prowadzą stała interakcję ze swoim otoczeniem, używając do tego sygnałów wejściowych i wyjściowych, które mogą być zarówno ciagłe jak i dyskretne

- odpowiadają na przerwania, tzn. reagować na zdarzenia o odpowiednio wysokim priorytecie, nawet jeżeli są zajęte innymi obliczenia$\mathrm{mi}$

- ich działanie i reakcje na sygnały wejściowe często muszą odpowiadać wysokim wymaganiom czasowym

- zmieniają swój stan w zależności od bieżącego trybu działania i wartości danych oraz od przeszłego zachowania 
- nie muszą być współbieżne, aczkolwiek najczęściej ich zachowanie może być przyrównane do komunikujących się procesów działających współbieżnie.

Do systemów reaktywnych należą układy sterowania binarnego, czyli takie, które na swoim wejściu i wyjściu operują wartościami binarnymi. Innym możliwym zastosowaniem

reaktywnego systemu sterującego jest jednostka sterująca w systemie przetwarzającym dane (ang. FiniteState Machine with Data Path). Taki model układu znajduje zastosowanie w cyfrowym przetwarzaniu sygnałów (ang. Digital Signal Processing) oraz stanowi podstawową

architekturę mikroprocesorów ogólnego przeznaczenia.

\section{Modelowanie dyskretnych systemów reaktyw- nych}

Do kompletnego opisu systemów reaktywnych można użyć automatu skończonego [2 i 5],

a szczególnie FSM (Finite State Machine - Skończona Maszyna Stanowa). FSM jest uogólnieniem automatu skończonego.

Maszyna o skończonej liczbie stanów FSM, zwaną również maszyną stanową lub automatem cyfrowym, jest najbardziej popularnym modelem opisującym zachowanie systemów sterowania, w którym chwilowe działanie systemu jest w sposób naturalny reprezentowane $\mathrm{w}$ formie stanów i przejść między nimi. Zasadniczo FSM składa się ze zbioru stanów, zbioru przejść między nimi oraz zbioru akcji przypisanych stanom lub przejściom. Stany maszyny stanowej, w najprostszym przypadku są określane jako partycja (podzielenie zbioru na niepuste i rozłączne części, które w sumie dają cały zbiór) na zbiorze wszystkich stanów obiektu.

\section{Mikrosystemy cyfrowe}

W projekcie badawczym autorzy zaproponowali strukturę rozproszonego sterowania w oparciu o mikrokontrolery PSoC (Programmable System on Chip) firmy CYPRESS. Układ ten różni się od typowych mikrokontrolerów tym, że posiada programowalne peryferia nie tylko cyfrowe, ale także analogowe. Schemat blokowy przedstawiono na rys. 3 .

Tę rodzinę układów wybrano ze względu na bogate możliwości programowego tworzenia układów analogowych z rekonfigurowanych bloków. Na zasoby analogowe składają się $\mathrm{m}$. in.

- wzmacniacz odwracający

- wzmacniacz pomiarowy

- wzmacniacz o programowanym wzmocnieniu

- komparator

- przetworniki AC inkrementalne, DeltaSigma, typu SAR (successive approximation register), 8 i 12 bitowe, pojedyncze, podwójne, potrójne

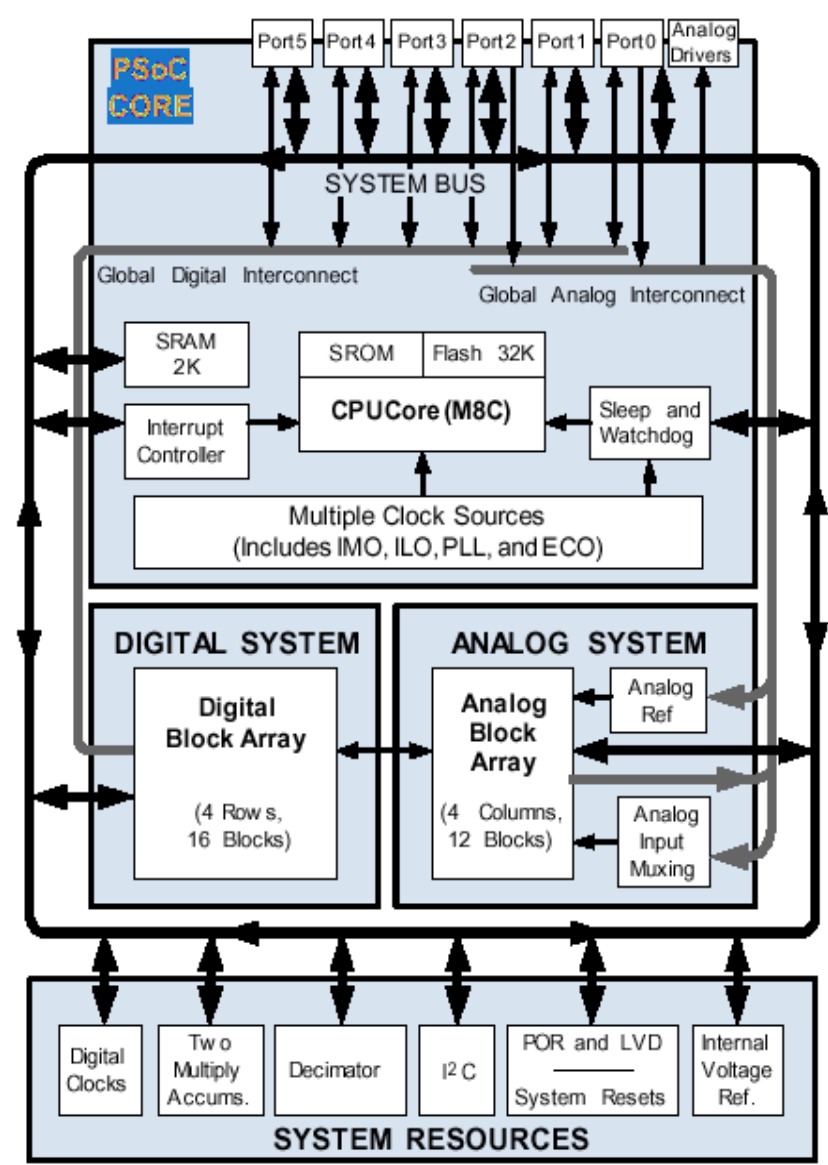

Rys. 3. Schemat blokowy mikrokontrolera PSoC CY29466 firmy CYPRESS

- moduly DTMF (Dual Tone Multiple Frequency)

- przetworniki DC

- filtry dolnoprzepustowe, środkowoprzepustowe

- modulatory szerokości impulsu PWM.

Wszystkie moduły analogowe zrealizowano w oparciu o blok z przełączanymi pojemnościami (Analog Switched Capacitor Block). Poprzez odpowiednią kombinację czasów ładowania i rozładowania poszczególnych pojemności można zrealizować układy rezystancyjne. Ponadto dostępne są układy cyfrowe: liczniki, timery, generatory pseudolosowe itp. Komunikację zapewniają moduły RS232, I2C, USB. Maksymalna częstotliwość zegarowa wynosi $24 \mathrm{MHz}$ z możliwością stabilizacji kwarcowej za pośrednictwem pętli synchronizacji fazowej

(ang. PLL - Phase Locked Loop) dla zadań pomiarowych.

Tworzenie oprogramowania jest możliwe za pomocą dwóch narzędzi:

\section{PSoC Designer}

- Umożliwia tworzenie oprogramowania z wykorzystaniem zaimplementowanych bloków funkcjonalnych uzupełnionych o programy $\mathrm{w}$ Asemmlerze (i/lub) języku C. 


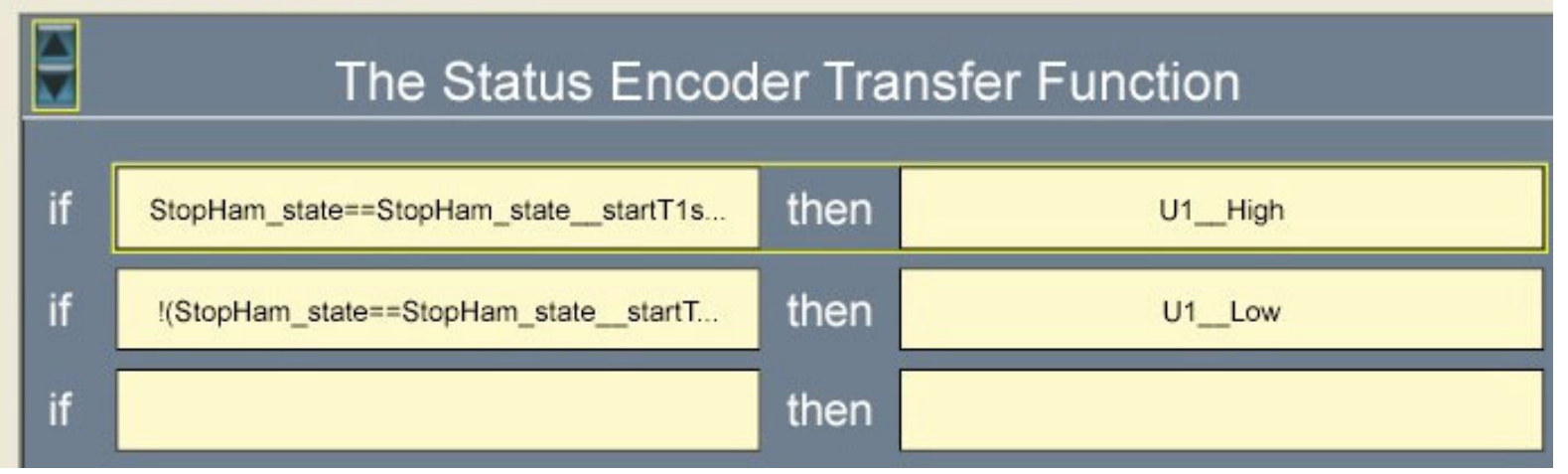

Rys. 4. Przykład programu PSoC Express

\section{PSoC Express}

- Przeznaczony jest do tworzenia programu w oparciu o zaimplementowane bloki funkcjonalne we/wy oraz funkcje przejścia. Funkcje przejścia mogą być:

- Kombinacyjne (Table Lookup)

- Warunkowe ( warunki w języku C) :

Status Encoder If $\mathrm{x} 1$ then $\mathrm{y} 1$ If $\mathrm{x} 2$ then $\mathrm{y} 2$

If $x 3$ then $y 3$

Priority Encoder If $\mathrm{x} 1$ then $\mathrm{y} 1$

Else If $\mathrm{x} 2$ then $\mathrm{y} 2$

Else If $\mathrm{x} 3$ then $\mathrm{y} 3$

- Stanowe (State Machine) - umożliwiają tworzenie programu w oparciu o sporządzony wcześniej graf automatu.

W projektowanych przez autorów układach wejściowo - wyjściowych zastosowano wszystkie wyżej wymienione metody tworzenie oprogramowania.

Na rys. 4 przedstawiono przykładowo sposób realizacji programu PSoC Express stanu wyjść U1. Przyjmuje ono stan logiczny „1” (U1_High) gdy graf „StopHam” jest w stanie „startT1s”, a stan logiczny „0" (U1_Low) gdy graf „StopHam” jest w stanie „startT"

Na rys. 5 przedstawiono przykładowy graf maszyny stanów. Stan początkowy to „HSOstan0”. Pod wpływem funkcji przejścia „1" maszyna stanów przechodzi ze stanu „HSOstan0” do stanu ,startTopHSO1”. $\mathrm{Z}$ tego stanu może powrócić do stanu początkowego, gdy będą spełnione wymagane warunki określone przez funkcję przejścia „,2”. Gdy natomiast będą spełnione warunki przejścia „3" maszyna stanów znajdzie się w stanie „HSOstan1”. Analogiczne rozumowanie można przeprowadzić dla funkcji przejścia „,4”, ,,5”, i „6".

\section{Przykłady rozwiązań}

W Zakładzie Elektrotechniki Instytutu Pojazdów Szynowych „TABOR” w Poznaniu zaprojektowano i wykonano oprogramowanie modułu akwizycji sygnałów analogowych i cyfrowych oraz sterowania

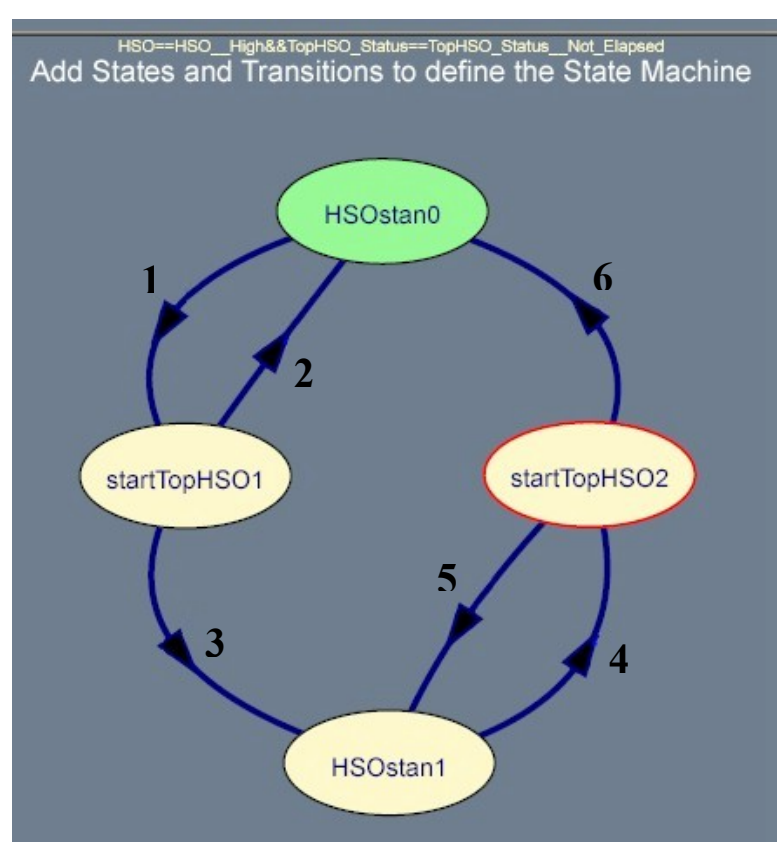

Rys. 5. Stany i tranzycje definiujące maszynę stanową

wyjść cyfrowych $24 \mathrm{~V}$ (rys. 6). Jest on wyposażony w 8 wejść analogowych, 7 wejść cyfrowych oraz 7 wyjść cyfrowych. Przykładowy program z wykorzystaniem tego modułu realizuje pomiar częstotliwości w 4 kanałach oraz zbiera dane cyfrowe z 6 wejść cyfrowych. Następnie całą zebraną informację przesyła do sterownika nadrzędnego za pośrednictwem łącza RS232.

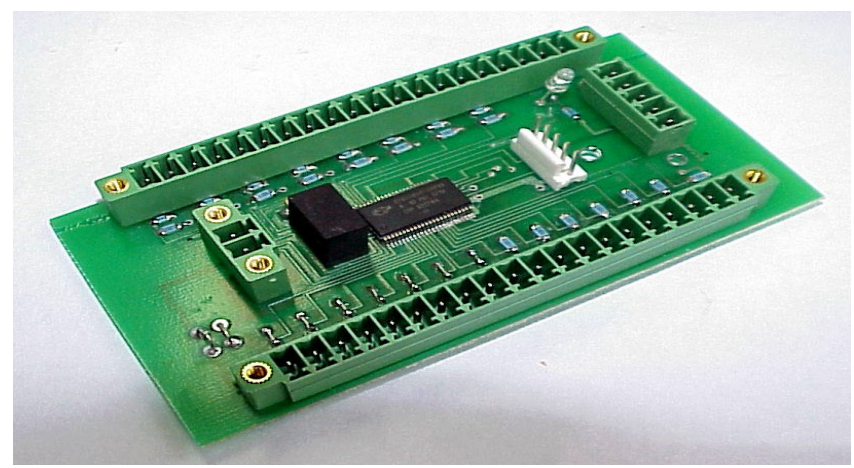

Rys. 6 . Widok przykładowego modułu mikroprocesorowego 


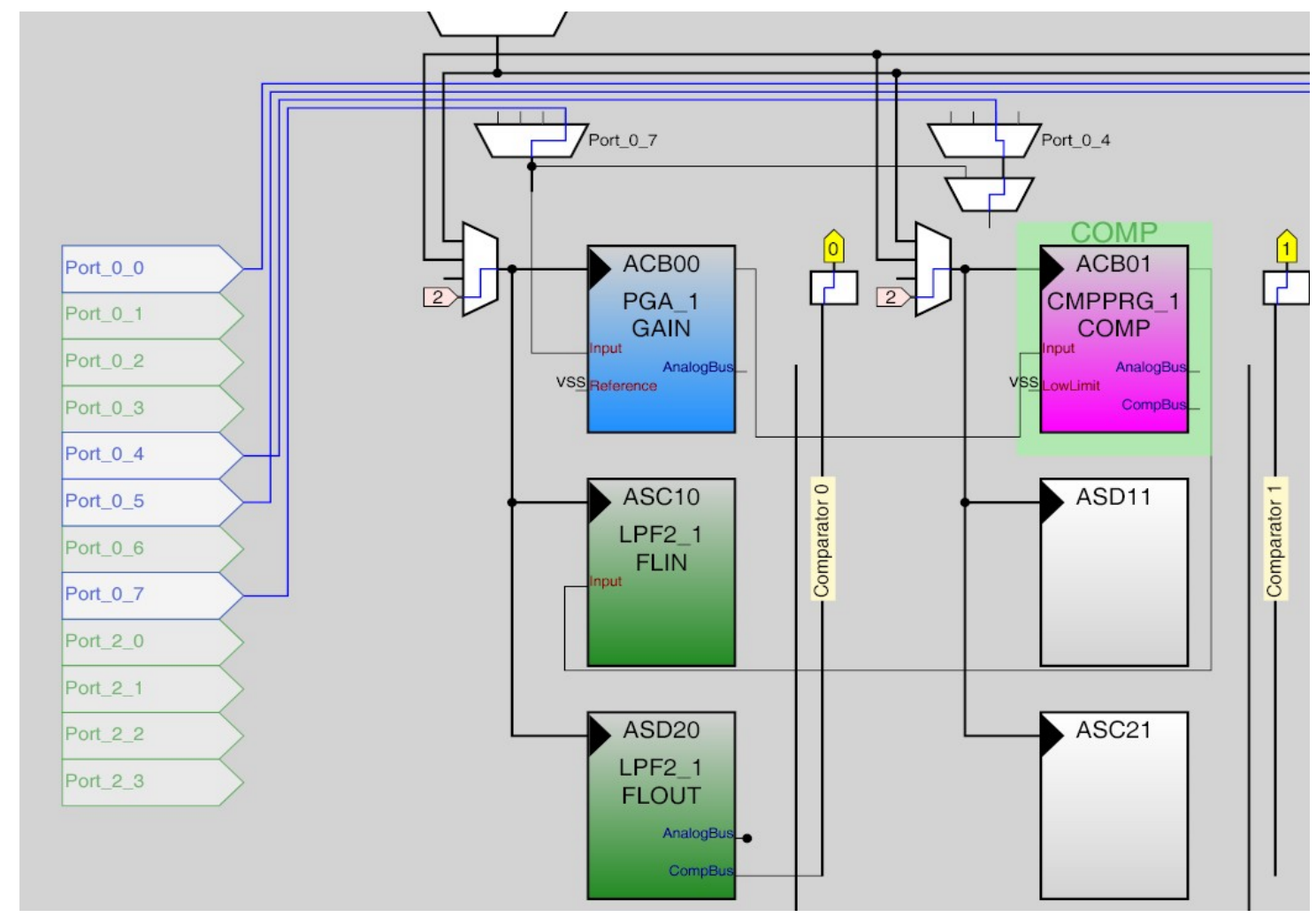

Rys. 7. Fragment programu Designer dotyczący części analogowej toru pomiaru

$\mathrm{Na}$ pomiar częstotliwości składają się następujące czynności:

- wzmocnienie wejściowego sygnału sinusoidalnego

- kształtowanie sygnału prostokątnego

- filtrowanie ew. wyższych częstotliwości

- realizacja programu do cyfrowy pomiar częstotliwości.

Część analogową pomiaru zrealizowano z wykorzystaniem zasobów analogowych mikrokontrolera PSoC (rys. 7).

Blok PGA 1 tego mikrokontrolera wzmacnia sygnał $\mathrm{z}$ wybranego za pośrednictwem multipleksera portu wejściowego. Po wzmocnieniu sygnał jest skierowany do bloku komparatora CMPPRG_1, a następnie uformowany sygnał prostokątny jest filtrowany w bloku filtra dolnoprzepustowego LPF2_1. Do programowania charakterystyki filtra służy program narzędziowy (rys. 8).

Uformowany $\mathrm{w}$ ten sposób sygnał wejściowy jest przekazany poprzez szynę Comparator0 do zespołu zasobów cyfrowych (rys. 9). Na część cyfrową składa się bufor wejściowy DigBuf_1, licznik 8-bitowy Counter8_2, bufor DigBuf_2, licznik 32-bitowy Counter32 1 , oraz modul transmisji TX8 1 . Bufor wejściowy odbiera dane z części analogowej, licznik 8bitowy służy do podziału częstotliwości przez 2, bufor DigBuf_2 służy do wygenerowania przerwania na zboczu opadającym sygnału pomiarowego a w liczniku 32-bitowym dokonywane jest zliczanie impulsów zegarowych o częstotliwości $12 \mathrm{MHz}$.
Po skonfigurowaniu zasobów procesora został napisany program główny $\mathrm{w}$ języku $\mathrm{C}$ do pomiaru częstotliwości w 4 kanałach (z wykorzystaniem przerwań) oraz akwizycji 6 wejść cyfrowych o następujących parametrach:

- kodowanie wejść cyfrowych:

- nr wejścia weC1 weC2 weC3 weC4 weC5 weC6

- nazwa zmiennej bajt1 bajt2

- kolejność transmisji: P0(7), P0(5), P0(3), P0(1), bajt1, bajt2

- prędkość transmisji 38400 bit/s.

Przykładowe działanie opisywanego programu przedstawiono na rys. 10 . Dla potrzeb testowania połączono wejścia analogowe do wspólnego, stabilnego źródła częstotliwości. Przedstawiono odebrane ramki dla częstotliwości $3000 \mathrm{~Hz}, 1000 \mathrm{~Hz}, 10 \mathrm{~Hz}, 1 \mathrm{~Hz}$ oraz stanu 6 wejść cyfrowych zakodowanych w kodzie hexadecymalnym. 
Filter Parameters

$$
\begin{aligned}
& F_{\text {Corner }}(\mathrm{Hz}): \sqrt{100000}(\mathrm{~Hz}): \sqrt{1000000} \\
& \mathrm{~F}_{\text {Sample }}(\mathrm{dB}): \sqrt{0.0}
\end{aligned}
$$

$\begin{array}{|rr|}\text { Calculated Values } & \\ \text { Damping Ratio (d): } & 1.414 \\ \text { Calculated d: } & 1.838 \\ \text { Scaled fo: } & 100000 \\ \text { Gain }(\mathrm{V} / \mathrm{V}): & 1 \\ \text { Calc Gain (C1/C2): } & 1 \\ \mathrm{C} 1: & 10 \\ \mathrm{C} 2: & 10 \\ \mathrm{C} 3: & 23 \\ \mathrm{C} 4: & 29 \\ \mathrm{CA}: & 32 \\ \mathrm{CB}: & 32 \\ & \\ \text { Divide by } \mathrm{n}: & 6 \\ & \\ \text { Column Clock (Hz): } & 400000 \\ & \\ \text { Oversample Ratio: } & 10 \\ \end{array}$

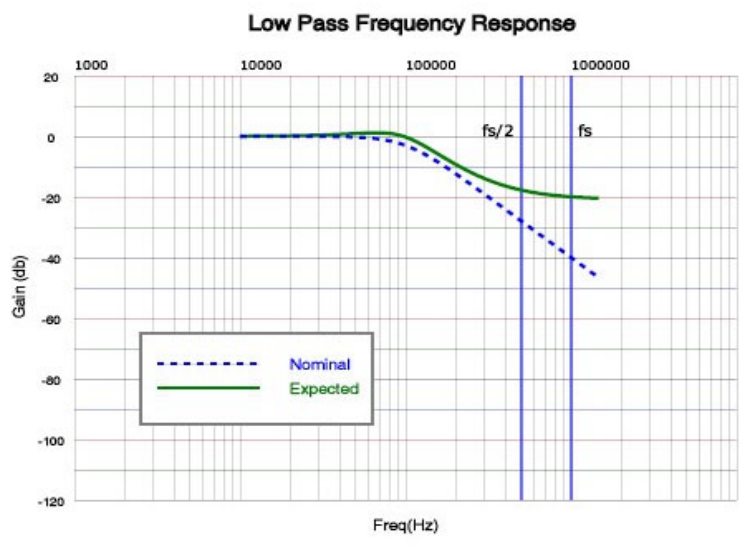

Rys. 8. Fragment programu Designer do doboru parametrów filtru dolnoprzepustowego

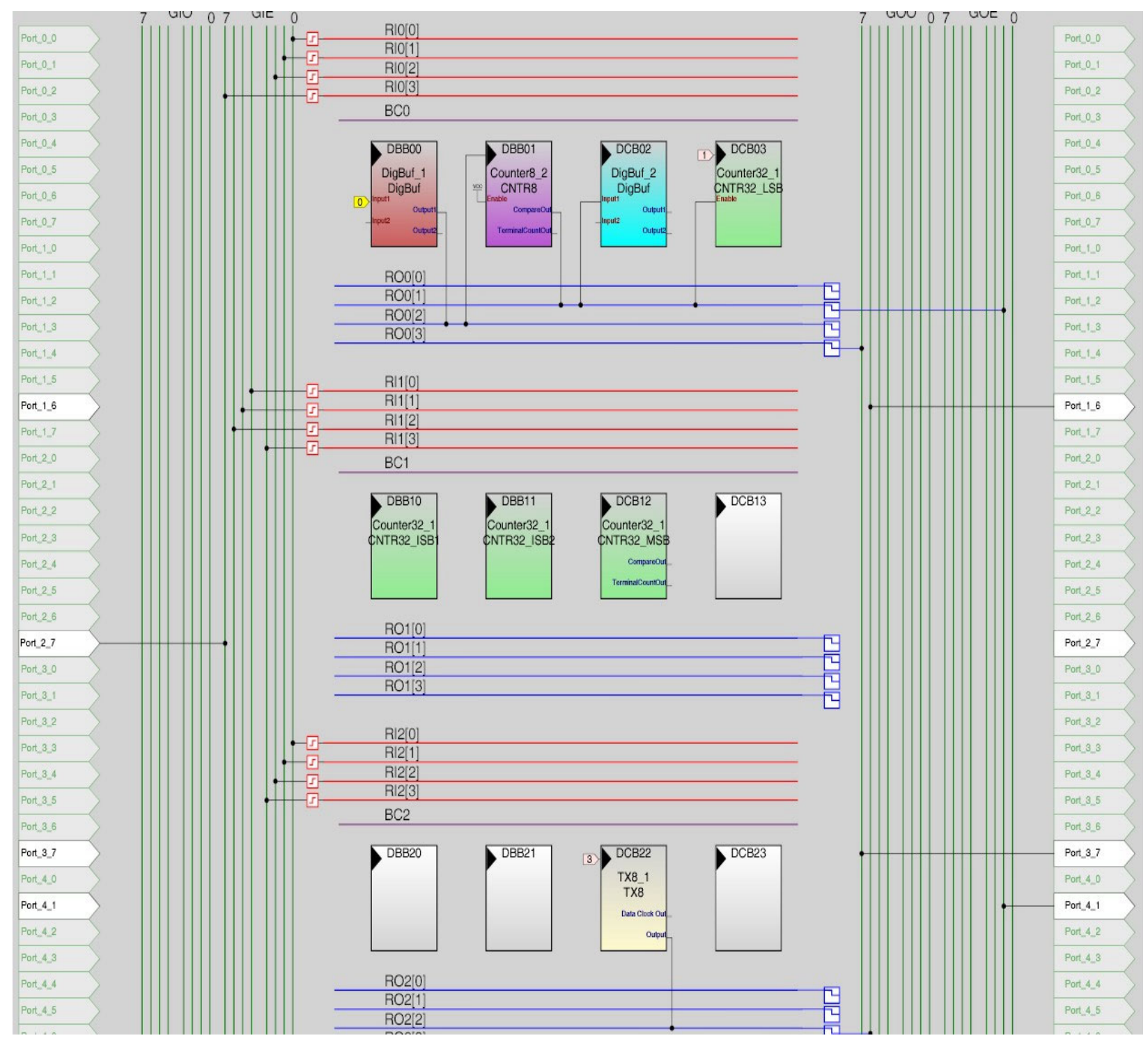

Rys. 9. Fragment programu Designer dotyczący części cyfrowej toru pomiaru 


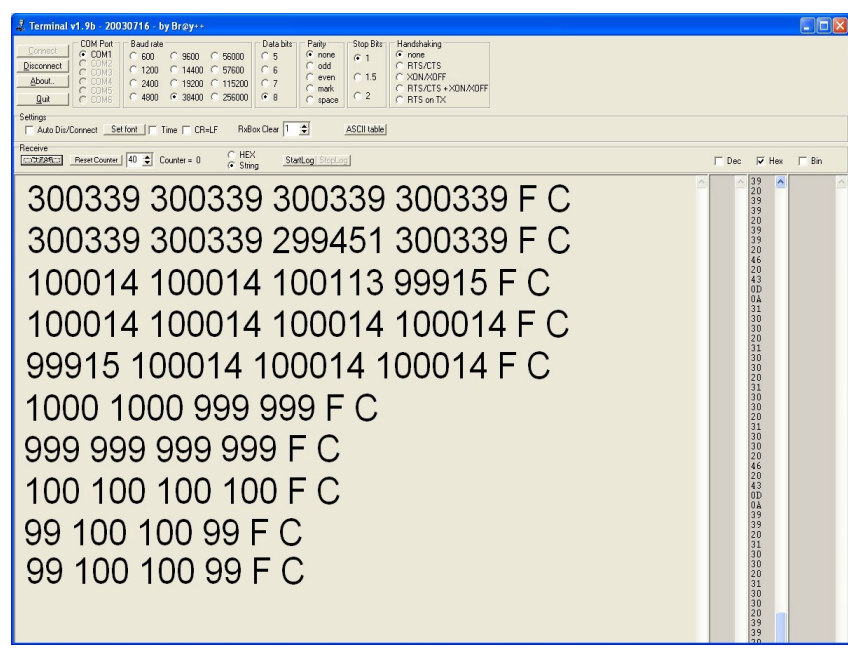

Rys. 10. Okno terminala

\section{Podsumowanie i uwagi końcowe o zastosowaniu mikrosystemów cyfrowych do realizacji ukła- dów wejść - wyjść na pojeździe szynowym}

W wyniku zastosowania mikrosystemu cyfrowego PSoC CY29466 w sterowaniu i diagnostyce pojazdu szynowego uzyskano układy, które mogą:

- realizować przesunięcie strefy cyfrowej (eliminacja klasycznego bloku analogowego) w kierunku sensorów pomiarowych, co polepsza własności pomiarowe, jak i dokładność i dynamikę zakresu pomiarowego

- tworzyć uniwersalne interfejsy do przetworników, co eliminuje nie tylko tradycyjne układy analogowe, lecz również przetworniki analogowo - cyfrowe (A/C)
- dla sygnałów wyjściowych zmniejszyć rolę przetworników cyfrowo - analogowych (C/A) i bloków analogowych

- wprowadzić cyfrowo sterowane układy wykonawcze, co poprawia dokładność, dynamikę sterowania procesem, zmniejsza wrażliwość na zakłócenia i zwiększa niezawodność pracy.

\section{Literatura}

[1] Bocian S.: Przyszłościowe wspótbieżne mikroprocesorowe inteligentne systemy mechatroniczne $w$ sterowaniu $i$ diagnostyce pojazdów szynowych (2). Pojazdy Szynowe nr $1 / 2008$

[2] Bocian S.: Przyszłościowe wspótbieżne mikroprocesorowe inteligentne systemy mechatroniczne $w$ sterowaniu $i$ diagnostyce pojazdów szynowych (3). Pojazdy Szynowe $\mathrm{nr} 2 / 2008$

[3] Ober J.: Stan i kierunki rozwoju systemów czasu rzeczywistego $w$ zastosowaniach przemystowych.

[4] Dokumentacja UIT dostepna pod adresem www.uniprod. com.pl

[5] Wolański P.: Modelowanie uktadów cyfrowych na poziomie RTL z wykorzystaniem sieci Petriego i podzbioru języka VHDL. Praca doktorska, Politechnika Warszawska, Wydziat Elektroniki i Technik Informatycznych, 1999. 